\title{
TRADUÇÃO E ESCRITA TESTEMUNHAL EM MÉMOIRES DE PRISON
}

\section{TRANSLATION AND TESTIMONIAL WRITING IN MÉMOIRES DE PRISON}

\author{
Aryadne Bezerra de Araújo* \\ Élida Paulina Ferreira \\ Zelina Márcia Pereira Beato Szachnowski ${ }^{\star \star \star}$
}

\section{RESUMO}

Propomos refletir sobre o processo tradutório do testemunho de Graciliano Ramos, Memórias do Cárcere (1954), ressaltando as marcas do contato com essa escrita "penosa" que a tradução de Antoine Seel e Jorge Coli, Mémoires de Prison (1988), põe em relevo O testemunho original relata a prisão arbitrária sofrida pelo autor durante a ditadura Vargas e a experiência traumática do cárcere. A narração dessas memórias sinaliza para o seu conturbado processo de escrita de situações limites, encenando a aporia que, segundo Jacques Derrida (2000b), comanda o processo tradutório: a necessidade dominante de traduzir e, ao mesmo tempo, as limitações da tarefa. Essa aporia atravessa as leituras do filósofo acerca do gesto testemunhal. Como afirma, ao apresentar-se como único sujeito a presenciar uma verdade, a testemunha recusa a traduzibilidade e a possibilidade de ser substituída (DERRIDA, 2000a), numa performance do que lemos nos últimos versos de Asbenglorie, por Paul Celan: ninguém testemunba pela testemunba. Contudo, Derrida (2000a) argumenta que o testemunho só tem valor quando é traduzível e, assim, comunicável. Considerando que a necessidade tradutória coexiste com a impossibilidade de sofrer e sobreviver no lugar da testemunha, enxergamos o primeiro obstáculo para os tradutores. Como repetir o testemunho de Graciliano, traduzindo suas feridas, diante da impossibilidade de testemunhar em seu lugar? Numa reflexão sobre tradução e testemunho, Marc Crépon (2006) sugere que, diante do desafio tradutório impossível, deve-se testemunhar o encontro com a escrita original e fazer da tradução o documento desse encontro. Ou seja, em vez de testemunhar pela testemunha, deve-se testemunhar, na tradução, as impressões do contato com o corpo textual ferido do original. Argumentamos que a escrita tradutória das Memórias se revela um processo de recriação em que seus tradutores foram tocados pelo peso da escrita do cárcere, forjando na tradução o testemunho das impressões diante do original.

Palavras-chave: Memórias do Cárcere; tradução; testemunho.

\footnotetext{
* Doutoranda em Letras - Linguagens e Representações pela Universidade Estadual de Santa Cruz, UESC, Ilhéus, BA, Brasil. aryadne.araujo@gmail.com

Bolsista da Fundação de Amparo à Pesquisa do Estado da Bahia (FAPESB).

Orcid: https://orcid.org/0000-0003-0645-9560

** Universidade Estadual de Santa Cruz, UESC, Ilhéus, BA, Brasil. epferreira@uesc.br Orcid: https://orcid.org/0000-0001-5513-9366

*** Universidade Estadual de Santa Cruz, UESC, Ilhéus, BA, Brasil. zell.beato@gmail.com

Orcid: https://orcid.org/0000-0002-1546-230X
} 


\section{ABSTRACT}

We propose a reflection on the translation process of Graciliano Ramos' Memoirs of Prison (1954), shedding light on marks of the contact with Ramos's "grievous" writing that its translation, Memoires de Prison (1988), by Antoine Seel and Jorge Coli, reveals. The original testifies to the arbitrary arrest the author suffered during Vargas' dictatorship and the traumatic experience witnessed in prison. In narrating these memories, he offers insights into the troubled writing process of extreme situations, enacting an aporia that, according to Jacques Derrida (2000b), commands translation: the imperative necessity of translating and, at the same time, this task limitations. This aporia extends to the philosopher's reflections on testimony. As he states, by presenting themselves as the only witness to a truth, the witness refuses translatability and the possibility of being replaced (DERRIDA, 2000a), performing the last verses of Paul Celan's Ashenglorie: nobody bears witness for the witness. However, Derrida (2000a) argues that testimony as such must be translatable and thus communicable. Given the imperative need for translation that coexists with the impossibility of suffering and surviving in the witness' place, the first obstacle for translators emerges. How can one repeat Ramos' testimony, translating his wounds, considering the impossibility of bearing witness in his place? Reflecting on translation and testimony, Marc Crépon (2006) suggests that, facing the impossible translation task, one must bear witness to the encounter with the original and make the translation into a document of this encounter. That is to say, instead of testifing for the witness, one testifies in translation one's own impressions of the contact with the wounded original text. As we argue, Memoires de Prison constitutes a process of recreation in which the translators were wounded by Ramos'tense writing, and which turned their translation into the testimony of their impressions in witnessing the orginal.

Keywords: Memoirs of Prison; translation, testimony.

\section{EM TORNO DAS MEMÓRIAS DO CÁRCERE}

Testemunho de um período de repressão e perseguição pela ditadura varguista, a narrativa das Memórias do Cárcere de Graciliano Ramos ainda se destaca entre os estudos que se ocupam da produção literária brasileira, especialmente em seu elo com a memória e os eventos históricos que constituem nossos traumas. Publicado em 1953, a relevância do testemunho de Graciliano estende-se aos dias atuais, fato ilustrado numa simples busca no catálogo online de teses e dissertações da CAPES. O livro é objeto de análise em aproximadamente trinta trabalhos defendidos a partir do ano de 2000, entre eles, mencionamos alguns em que a questão da escrita literária do trauma parece-nos manifesta: a tese de Ana Maria Abrahão dos Santos Oliveira (2014), intitulada Memória, testemunbo e escrita melancólica em Memórias do cárcere e Infância, de Graciliano Ramos e a dissertação O gesto autoral e o testemunbo em Memórias do Cárcere, de Valeria Gomes Ignacio da Silva (2015).

Se, por um lado, o livro testemunhal de Graciliano é inspiração para inúmeros estudos que refletem sobre o elo entre memória, trauma e escrita, no que concerne à discussão em torno da sua tradução, a quantidade de estudos é 
exígua. Os trabalhos sobre Memórias do Cárcere que mais se aproximam do estudo da tradução são aqueles que investigam a adaptação cinematográfica da obra por Nelson Pereira dos Santos, como as dissertações: Imagens do cárcere: do texto literário à leitura cinematográfica (MARTINEZ, 2002) e A obra literária e cinematográfica de Memórias do cárcere de Graciliano Ramos: o cárcere como metáfora da sociedade e a ficção como busca da libertaçãa (PAVERCHI, 2004). Sobre a tradução interlingual, a que Jakobson (1995) também designava como "tradução propriamente dita", não encontramos nenhum trabalho em torno do processo tradutório das Memórias.

A ausência de reflexões sobre o testemunho de Graciliano em outra língua diverge da pertinência da obra, não apenas no contexto nacional, mas no horizonte de uma modernidade marcada por ditaduras, regimes totalitários e a consequente violência de Estado.

A adaptação de Nelson Pereira, de 1984, testemunha a significância da obra e a sua capacidade de traduzir outros presentes históricos de repressão. O filme foi lançado em meio aos últimos suspiros de uma outra ditadura instaurada com o golpe militar de 1964, fato que sinaliza para a importância da leitura das Memórias do cárcere a fim de entendermos as feridas abertas pelos regimes autoritários e como sua lógica se repete. Tanto no regime ditatorial do qual Graciliano foi testemunha, como naquele prestes a findar durante o lançamento do filme, fazem-se presentes as repressões, a construção de um inimigo da nação, a saber, o comunismo e seus "defensores", a perseguição a pessoas que demonstravam qualquer sinal de simpatia por ideais comunistas, ou a críticos da ordem social então vigente. A tradução intersemiótica empreendida por Nelson Pereira constitui também o seu testemunho do estado de exceção instaurado quase três décadas após a prisão sofrida por Graciliano Ramos. Assim como o fez o escritor, o cineasta, nas palavras de Novaes e Souza (2018, p. 102),

em seu Memórias do Cárcere, também estava tratando da repressão política e da função do intelectual naquele momento em especial, à época do processo de "redemocratização do país" e, portanto, ainda a partir do núcleo traumático das prisões e torturas impostas pela ditadura militar instalada em 1964. De certa forma, o filme fazia parte do corpus de obras que, no momento da abertura política no início dos anos 80, iniciava o longo processo de luto coletivo, o qual, como sabemos, ainda não terminou, mas que não deixava de ser uma forma de afirmar, mesmo precariamente, uma "sensação de liberdade".

A releitura e a tradução do livro de Graciliano por Nelson Pereira constituiu, portanto, meio de denunciar as violências do estado de exceção do qual o cineasta foi testemunha. Tal acontecimento permite-nos apreender o aspecto exemplar do testemunho de Graciliano Ramos no que diz respeito à denúncia da repressão executada por regimes ditatoriais. 
Para além do teor de denúncia que constitui o testemunho, nossa leitura se volta para outro aspecto que julgamos exemplar nas Memórias do cárcere: a conturbada relação entre língua e memória na escrita das feridas deixadas pela punição sofrida, desprovida de acusação, e como essa tensão se desdobra na tarefa tradutória.

A despeito de tais aspectos exemplares do livro no que toca a questões de violência de Estado e de escrita testemunhal, observamos que a investigação do seu processo tradutório é exígua, estando basicamente relacionada à tradução intersemiótica, como afirmamos anteriormente. Porém, não só o estudo desse processo é escasso. Também, o número de traduções é limitado, existindo apenas a tradução para a língua francesa. A inexistência de outras traduções é fato curioso e leva-nos a relacioná-lo ao número precário de trabalhos em torno do processo tradutório desse livro.

Haja vista a carência de discussões nesse âmbito, propomos contribuir para o estudo do testemunho de Graciliano Ramos, trazendo à tona uma reflexão sobre sua tradução.

\section{BLESSURE E A POSSIBILIDADE IMPOSSÍVEL DE REPRESENTAÇÃO NA ESCRITA TESTEMUNHAL E TRADUTÓRIA}

Uma vez que dedicaremos espaço à tradução das Memórias, é relevante abordar uma discussão em torno das aporias que envolvem a tradução e a escrita testemunhal. Tal discussão será guiada pelas reflexões que Jacques Derrida (2000b, 2004, 2005) dedicou à escrita testemunhal e à tradução como práticas da Différance - neografismo que ele opera na língua francesa através da substituição da letra "e" pela letra "a" na palavra différence, fazendo encerrar nela, ao mesmo tempo, duas significações do verbo diferir.

Um desses sentidos aponta para a ação de diferir no espaçamento, ou seja, no entre-lugar em que uma suposta verdade, um sentido ou um acontecimento que se queira arquivar na escrita não se apresentará como presença incontestável e idêntica a eles mesmos, mas como um rastro de um acontecimento já ausente, rastro que, na ausência de um "querer-dizer" "original", abriga a experiência disseminal da escrita nas infinitas possibilidades de leituras por vir.

Essa diferença na repetição através da escrita é condição de qualquer experiência de linguagem. Mesmo o que se compromete a testemunhar na fala já está subordinado a uma ausência que a língua suplementa, mas que, como uma condição do suplemento, não traz à presença o "elemento" que falta ou que se ausenta, ou seja, não (re)constitui nas palavras o acontecimento testemunhado tal 
como ele foi. A diferença no espaçamento, nesse rastro de uma significação ausente, abala, portanto, o terreno da representação do trauma, visto que tal representação é demandada no relato testemunhal que, por sua vez, deve tornar o acontecimento testemunhado "presente" nas palavras da testemunha. Assim, qualquer outro, ao ouvi-la, poderá testemunhar a verdade do seu relato (DERRIDA, 2000a), porém, essa "verdade" não se subtrai a uma presença estável e incontestável na língua, falada ou escrita. A ressignificação da cena traumática ou de uma violência sofrida lida com a separação, no instante da escrita, com o instante que se quer, nela, guardar. Por conseguinte, lida-se com a ausência perturbadora de uma "verdade" testemunhada, mas, ao mesmo tempo, fala-se alguma coisa da cena e do sofrimento que, de outro modo, não seria comunicado.

$\mathrm{Na}$ separação com o instante e com a verdade que se jura "entregar", a escrita testemunhal abriga uma tensão entre a promessa de fidelidade e a différance na ausência absoluta do que se compromete a traduzir no relato. Observamos o testemunho dessa tensão nas justificativas elaboradas por Graciliano Ramos no capítulo introdutório das suas Memórias do cárcere, respondendo a um possível questionamento acerca da demora do relato. A primeira razão para iniciar a escrita somente após dez anos da sua prisão é, como relata, a ausência das anotações com as quais se ocupava durante os meses vividos em cárcere. Tais notas estariam mais próximas do presente em que as asperezas sofridas e relatadas tiveram lugar, estariam, também, mais próximas dos sujeitos que compartilhavam o espaço prisional, com os quais o autor "firma" um compromisso de "fidelidade" - compromisso que lemos nas suas palavras: "fiz o possível por entender aqueles homens, penetrar-lhes na alma, sentir suas dores, [...]. Foram apenas bons propósitos: devo ter-me revelado com frequência egoísta e mesquinho" (RAMOS, 1954, vol. 1, p. 11).

Mesmo próximas, essas anotações não constituiriam outra coisa senão o suplemento na ausência dos fatos e dos sujeitos retratados. Mas a falta delas parece representar a ruptura de um último fio com o qual se acreditava costurar aquela realidade a um presente posterior. Em referência às anotações, Graciliano (1954, p. 5) afirma: "Não conservo notas: algumas que tomei foram inutilizadas, e assim, com o decorrer do tempo, ia-me parecendo cada vez mais difícil, quase impossível, redigir esta narrativa". Como resultado dessa distância dos acontecimentos, a licença e um certo pedido de desculpas pelas hesitações, dúvidas e vacilações preenchem as folhas da introdução. As hesitações e as dúvidas constantes são os sintomas de um corte entre um passado traumático e sua inscrição num corpo textual, corte que toma a forma de uma ferida que incomoda - tanto o escritor como o leitor tradutor - ao abrir-se ao movimento ininterrupto da différance. Diante desse movimento que 
"alarga" a ferida no texto, "dúvidas terríveis" e "vacilações dolorosas" encontram morada no processo testemunhal e tradutório.

Outra leitura implicada no pensamento da différance refere-se ao diferimento no tempo, isto é, ao adiamento do encontro prometido nos atos de fala ou escrita com uma origem, uma verdade, um destino ou um sentido pretendido (DERRIDA, 1991). Esse adiamento infinito do encontro com uma "verdade" original condena a tradução à impossibilidade de cumprir sua tarefa, isto é, de transportar uma tal verdade a outra língua, de dizer "o mesmo" com outras palavras, de ser fiel a uma voz autoral que se supõe encriptada no texto. Ora, como (re)escrever "o mesmo", se esse "mesmo" já é outro desde a primeira escrita, desde a primeira ruptura com uma suposta identidade de seu sentido? O rastro é o que resta desse "mesmo" na escrita, desse "querer-dizer" não mais presente que não cessa de se deslocar. A tradução parte, portanto, não de um suposto sentido presente no texto de partida, mas de rastros desse "sentido", ou, se tratando de uma narrativa testemunhal, rastros de um trauma, de uma ferida que os tradutores devem testemunhar na tradução.

Avistamos esse adiamento de uma "verdade" pretendida no "original" na leitura que os tradutores, Antoine Seel e Jorge Coli, fazem sobre o processo de criação de Graciliano Ramos. Seel e Coli (1986, p. 66) reconhecem nesse processo a busca por um âmago, "feito apenas de palavras necessárias", que, por uma desconfiança interminável (na capacidade tradutória da língua), não cessa de escapar. Isso que os tradutores dizem sobre a escrita de Graciliano, quando estavam a traduzir suas Memórias, nos dá sinal da leitura que eles mesmos engendram do texto. Portanto, o "âmago" que, para eles, Graciliano busca atingir não é nada menos que o "âmago" que eles mesmos anseiam encontrar, ou seja, o segredo da escrita que buscam revelar na tradução, a "verdade" última cujo atingimento está eternamente adiado.

Nesse encontro adiado e nesse segredo que resiste inapropriável atesta-se a cesura com uma origem e um fim, com um acontecimento que se quer conservar presente, com um presente testemunhável que se quer colocar à prova de qualquer leitor disposto a escutar o testemunho do outro. Tal cesura é signo de uma marca abandonada, pois, aludindo ao que se lê em Derrida (1991), escrever é abandonar uma marca, e é, também, signo de uma alteridade inapropriável que, diante da impossibilidade de apropriação do outro, da sua marca e do seu testemunho, cede lugar à experiência disseminal da língua. Nessa experiência, torna-se irrefutável a possibilidade de infinitas leituras que desloquem uma dada escrita a destinos inesperados e incertos, reafirmando a separação dessa escrita do instante 
da sua criação e das intenções, de ordem semântica, discursiva ou literária, que impulsionaram sua existência. Nesse sentido, Derrida (2003) afirma:

A experiência que chamo disseminal faz e assume, através do momento hermenêutico mesmo, da hermenêutica mesma, a prova de uma interrupção, de uma cesura ou de uma elipse, de um corte. Tal abertura não pertence nem ao sentido, nem ao fenômeno, nem à verdade, mas, tornando-os possíveis em sua restância [restance], ela marca no poema o hiato de uma ferida cujos lábios não se fecham ou não se juntam jamais (DERRIDA, 2003, p. 54, tradução nossa) ${ }^{1}$.

O corte, a ausência e, ao mesmo tempo, um luto e uma lamentação pelo que não se conservou presente na escrita formam o terreno para se pensar a ferida ou o trauma na língua. Quando se quer converter outra ferida no corpo da língua, como ocorre nas Memórias do cárcere, esse corte na escrita é ainda mais perturbador, uma vez que o trauma em si demanda representação na língua (SELIGMANN-SILVA, 2005). A representação do trauma, pelo acontecimento da cesura no corpo textual, permanece, assim, como uma promessa impagável (Derrida, 2000b).

A conversão do trauma na língua abre uma ferida, separando a escrita do presente traumático, que deve traduzir outra ferida, ou seja, deve traduzir o trauma que da escrita é segregado, na ausência dele, fora do instante da sua eclosão. Tal é a tensão que podemos ver no conflito entre a testemunha Graciliano e a língua, ao pôr em questão o próprio relato: "o ato que nos ocorre nítido, irrecusável, terá sido realmente praticado? Não será incongruências?" (RAMOS, 1954, p. 10).

A ausência, a lacuna, o hiato, a ferida engendram a escrita. É para cicatrizar essa ferida, para preencher a lacuna que a escrita é demandada. Mas essa costura, esse fechamento não se finda. Resiste um espaçamento, uma différance entre o trauma e a língua. Essa différance na representação do trauma é o corte que não se fecha na sonhada união entre um "querer-dizer" ou, melhor, um "querer-testemunhar" e o que as palavras escritas dizem/testemunham. Nesse espaçamento, a experiência disseminal demora-se, fazendo surgir, noutras leituras, outras feridas.

Observamos de forma manifesta a experiência disseminal da cesura nas leituras que Derrida (2004) faz do poema Aschenglorie de Paul Celan e das suas traduções em Poétique et politique du témoignage. Além dessas reescritas, o filósofo propõe outra possibilidade de leitura por meio de uma tradução que ele mesmo elabora. O poema na língua de partida e sua inscrição nessas outras línguas são envolvidos numa discussão acerca da singularidade do testemunho e da linguagem

1. "l'expérience que j'appelle disséminale fait et assume, à travers le moment berméneutique même, à même l'berméneutique, l'épreuve d'une interruption, d'une césure ou d'une ellipse, d'une entame. Telle béance n'appartient ni au sens, ni au pbénomène, ni à la vérité mais, les rendant possibles en leur restance, elle mardue dans le poème le biatus d'une blessure dont les lèvres ne se ferment ou ne se rassemblent jamais" (DERRIDA, 2003, p. 54). 
poética de Celan. Na reflexão, vemos como as traduções atestam tal singularidade, no momento mesmo em que se propõem a repetir o poema em outro idioma. Cada tradução, conforme a reflexão de Derrida, não repete o poema "enquanto tal", mas traz à luz novas possibilidades de escrita e significação, atestando a impossibilidade de testemunhar no lugar do outro, aos mesmos acontecimentos aos quais a testemunha sobreviveu. Essa impossibilidade liga-se também, como veremos, à intraduzibilidade do testemunho. Por outro lado, o testemunho demanda tradução como forma de "revelar" uma verdade que apenas a testemunha conhece e como um compromisso de pôr à prova essa "verdade", oferecendo-a ao testemunho do outro, do ouvinte, do leitor e do tradutor (DERRIDA, 2000a).

$\mathrm{Na}$ reflexão sobre o poema de Celan, Derrida (2004) aborda, por exemplo, a intraduzibilidade da primeira palavra e título do poema, "Aschenglorie", palavra criada a partir da união de duas expressões, "aschen" (cinzas) e "glorie" (glória). Já no título, testemunha-se um obstáculo para uma tradução palavra por palavra. Os tradutores confessam essa dificuldade, ao traduzir esse corpo único em três signos (cendres-la gloire, gloire de cendres) ou em dois (ash-glory) ${ }^{2}$.

Para além desse obstáculo formal, outra questão muito próxima da intrincada relação entre língua e trauma se desenha no signo Aschen que carrega, possivelmente, o testemunho da tentativa de reduzir a cinzas a possibilidade de se testemunhar os campos de extermínio. Derrida, então, afirma: "a língua alemã desse poema terá sido presente em tudo que se pôde destruir pelo fogo e reduzir a 'cinzas' (Cinzoglória é a primeira palavra do poema, uma palavra dupla e dividida) as existências em número inumerável - inumeravelmente" (DERRIDA, 2004, p. 68, tradução nossa) ${ }^{3}$.

Em vista desse argumento sobre o testemunho "privilegiado" da língua, podemos pensar que, mesmo existindo uma palavra "equivalente" a Aschen em diversas circunstâncias de comunicação, os efeitos que tal signo provoca serão distintos e singulares para o leitor herdeiro dos traumas da segunda guerra. A simples evocação dessa palavra poderá trazer à memória o sentido de aniquilação

2. O próprio Derrida (2004) confirma a intraduzibilidade desse neologismo ao propor outra possibilidade de tradução para "gloire pour les cendres" (glória para as cinzas/ glória pelas cinzas). Possibilidade esta que ainda se mostra insatisfatória para o filósofo. Por outro lado, o poeta e tradutor Piero Eyben (2012) parece dar conta da tradução desse neologismo para o português, ao propor uma intervenção na língua de chegada, forjando uma nova palavra a partir de dois termos, assim como no poema original. Aschenglorie na sua tradução se torna "Cinzoglória". Noutro momento do presente texto, nos apropriaremos do termo que o tradutor cria, para traduzir uma citação em que Derrida faz referência ao poema.

3. Original: "La langue allemande de ce poème aura été présente à tout ce qui a pu détruire par le feu et réduire en 'cendres' (Aschenglorie, c'est le premier mot du poème, un mot double et divisé) des existences en nombre innombrable innombrablement". 
pelo fogo das inúmeras vítimas do nazismo. Celan evidencia à tradução que a língua e o corpo verbal do poema permanecem irredutíveis a uma assimilação que neutralize o caráter testemunhal das palavras alemãs da sua escrita.

Além desse obstáculo, os últimos versos do poema lançam luz sobre uma impossibilidade que também é uma barreira tradutória. Niemand/ zengt für den/Zengen ${ }^{4}$ nos diz que "ninguém testemunha pela testemunha", e, nesse sentido, ninguém tampouco pode substituir suas palavras (CRÉPON, 2006), o que, por conseguinte, anuncia a tradução como possibilidade interdita.

Para esses versos, Derrida (2004) oferece três possibilidades de leitura, entre as quais seria impossível decidir, restando um segredo quanto ao "verdadeiro" sentido nessas últimas linhas. Como primeira possibilidade de interpretação, ele questiona se o que os versos dizem "se trata de testemunhar a favor de alguém (testemunho para você, testemunho a seu favor, sou testemunha de defesa, etc.) ?"5 (DERRIDA, 2004, p. 534). Nesse caso, refutar-se-ia a possibilidade de testemunhar a favor de alguém no tribunal, como um terceiro num acontecimento que, paradoxalmente, envolve duas partes. A segunda leitura guia-nos para a constatação de que ninguém pode testemunhar no lugar da testemunha, não sendo possível assumir o seu lugar "privilegiado", no instante em que apenas ela esteve presente e viu, ouviu ou sofreu aquilo que se propõe a relatar. A última possibilidade de significação seria a de que ninguém testemunha diante da testemunha, ou seja, ninguém entrega seu relato a outro na intenção de que esse outro se torne também uma testemunha, uma vez que "uma testemunha, como tal, jamais está em posição de receber o testemunho de um outro, nem está autorizada a fazê-lo"6(DERRIDA, 2004, p. 534).

A leitura dessas impossibilidades elucidadas por Derrida pode vir a refutar um alargamento no conceito de testemunha como propõem algumas reflexões em que se torna aceitável, por exemplo, a proposição de que também pode ser uma testemunha aquele que ouve o relato insuportável do outro e leva adiante sua história. No entanto, não se trata de negar a probabilidade de uma experiência traumática ter lugar na escuta do sofrimento ou do choque que aflige o outro. Questiona-se, com Derrida (2004), a possibilidade de ser testemunha de uma dor, de uma perda ou da morte que não está "presente" na sua memória, mas no que se

4. Entre as possibilidades tradutórias, temos: "ninguém/ testemunha pelo/ testemunho" (tradução de Piero Eyben, 2012) e "ninguém testemunha pela testemunha" (tradução proposta por SeligmannSilva, 2005, p. 112). Optamos pela última por julgar que ela expressa de forma mais enfática o problema em questão: a impossibilidade de se transmitir o testemunho de modo que outra pessoa possa testemunhar pela testemunha, que alguém possa testemunhar em seu lugar.

5. "s'agit-il de témoigner en faveur de queldu'un (je témoigne pour toi, je témoigne en ta faveur, je suis un témoin de la defense, etc.)?"

6. Un témoin, en tant que tel, n’est jamais en situation de recevoir le témoignage d'un autre, ni babilité à le faire. 
ouve nas palavras da testemunha afetada pelo trauma. Em vista dessa limitação do testemunho, o tradutor - que já está comprometido a transportar adiante um relato "original" - testemunharia o presente da leitura do relato traumático do outro e a perturbação que ele pode incitar, ao ponto de se tornar um imperativo testemunhar o encontro com esse relato, levando adiante as impressões da leitura "penosa" através da tradução.

As três possíveis interpretações para a impossibilidade do gesto testemunhal, que Derrida propõe, permanecem como possibilidades de leitura entre as quais não se pode eleger uma como o sentido "por trás" dos versos de Celan. Essa análise que não aponta para um único e "verdadeiro" sentido revela-se performance do segredo indecifrável do testemunho, ou da escrita, de um modo geral, segredo que vozeia a asserção "ninguém testemunha pela testemunha". Logo, ninguém testemunha todas as feridas que se pretendeu traduzir na escrita, por exemplo, das Memórias do Cárcere, e nenhum leitor poderá esgotar todas as verdades e todos os traumas em volta dos quais esse texto continua a falar e a testemunhar.

Entrevemos, na leitura dos tradutores, a percepção de um segredo inesgotável na escrita do Cárcere, quando notam, nessa escrita, uma dúvida que "se interroga sobre uma verdade que deve existir em algum lugar" (COLI, SEEL, 1986, p. 66). Falam, também, da incerteza do autor quanto à capacidade da língua em expressar tal verdade. Duvida-se, portanto, se essa "verdade" é revelada pela língua de Graciliano Ramos, na sua escrita. Se os tradutores escrevem sobre uma verdade que se "esconde" no texto de partida, é porque esse aspecto surge a eles de modo que devem anunciá-lo, como uma inquietação e, talvez, um limite para sua tarefa. Ao notar tal incerteza, os tradutores dão testemunho de uma "verdade" que não está entregue no texto, de um "segredo" guardado, "em algum lugar", entre as reminiscências escritas.

À impressão de uma "verdade" que se impõe secreta, vem se juntar a ideia de um "âmago", como demonstramos anteriormente, que a escrita das Memórias busca atingir, "embora esse âmago, pela desconfiança interminável, pareça continuamente escapar" (COLI; SEEL, 1986, p. 66).

A leitura dos tradutores acerca da escrita original não é, portanto, menos identificável com o pensamento do segredo de que Derrida $(2004,2007)$ fala acerca da escrita poética e do testemunho, em especial, mas também de qualquer escrita. A dimensão secreta do texto corresponde à alteridade, a esse limite intransponível entre o eu leitor/tradutor e o outro escritor. Alteridade que barra a identificação completa entre esses dois sujeitos e a "revelação" de uma "verdade" secreta no 
original, mas que, por outro lado, impulsiona a busca por essa verdade nas leituras e traduções.

Esse segredo é, também, conforme o pensamento derridiano, a ferida cuja existência, na escrita do outro, se testemunha. É também como um trauma na medida em que se impõe como um resto indizível, malgrado as intermináveis tentativas de apreendê-lo e torná-lo "presente" e "testemunhável" na língua da tradução.

Essas tentativas de traduzir um resto indizível ou a ferida na escrita do outro não logram reduzir as possibilidades de representação e leitura a uma suposta "verdade", a um suposto "âmago" ou "segredo". Ao contrário, elas colocam em curso a experiência disseminante, por meio da qual os poemas e os textos de qualquer sorte continuam a falar e a fazer sentido a seus incontáveis e imprevisíveis "destinatários". Tentar esgotar esse segredo, barrando outras interpretações, seria um esforço que não teria outro propósito senão o violento ato de fechar a "boca" falante do texto, unir os "lábios" da ferida para que ela não se ofereça mais ao testemunho de outras leituras (DERRIDA, 2007). Restará sempre uma marca de que nem tudo pôde ser dito ou traduzido.

$\mathrm{Na}$ tradução Mémories de Prison, um sintoma desse resto intraduzível é, por exemplo, as palavras que os tradutores não traduzem e as notas explicativas para elas ou para as quais elaboram uma tradução. Confessam, desse modo, que a tradução não seria suficiente para "revelar" uma tal "verdade" que se pode testemunhar na língua original. Entretanto, como eles mesmos notam, Graciliano Ramos já expressava uma incerteza quanto à possibilidade de se testemunhar uma "verdade" por meio da língua. Ainda assim, optam por deixar algumas palavras não traduzidas, talvez na esperança de que elas permitissem a escuta dos traumas dos quais a língua de Graciliano foi testemunha "privilegiada". Servem-nos de exemplo as palavras que evocam as feridas abertas em séculos de escravidão na formação do Brasil, como no trecho em que Graciliano compara o espancamento de presos políticos a esse passado terrível de crueldade: "mais une raclée - grand Dieu! C'etait la dégradation irrémédiable. Cela rappelait l'eito, la senzala, le tronco, le feitor, le capitão-demato $^{\prime \prime 7}$ (RAMOS, 1988, p. 133).

O sentimento de que a tradução não basta, cujos sinais vemos nas palavras não traduzidas e nas notas, é coerente com o que Crépon (2006) argumenta sobre

7. O trecho corresponde ao momento em que Graciliano expressa sua indignação ao saber das torturas infligidas em três presos políticos e militares envolvidos na revolta de 1935 em Natal. Em nota de rodapé, os tradutores apresentam a definição das palavras não traduzidas: "termes liés aux travaux et aux châtiments des eslaves. Eito: champ où travaillaient les eslaves; senzala: cf. note 2, p. 53; tronco: poteau où l'on attachait les eslaves pour les rouer de coups; feitor: homme chargé de superviser le travail et les châtiments des eslaves; capitão-de-mato: individu chargé de capturer les eslaves fugitifs" (RAMOS, 1988, p. 133). 
a resistência tradutória no testemunho, por um lado, e o imperativo da tarefa, por outro. $\mathrm{O}$ autor afirma que, na poética de Celan, a resistência é ainda maior, não apenas por se tratar de um poema, desse acontecimento singular que, segundo Derrida (2004), recria, na "sua" língua, um idioma ou uma linguagem poética própria, irredutível a conteúdo de sentidos dados e, portanto, intraduzível. Mas a barreira à tradução também consiste no fato de que seus poemas, escritos em alemão, testemunham traumas dos quais a língua alemã foi testemunha privilegiada, como já elucidamos.

Nessa lógica que barra a tradução como simples substituição das palavras da testemunha, é concebível assimilar também a língua de Graciliano Ramos como testemunha "privilegiada" dos seus traumas. Na Explicação Final anexa ao livro, os tradutores testemunham a intraduzibilidade da palavra "tamancos" e o peso que assumem na cena do trauma: "et il cherchait à s'orienter grâce à des souvenirs, sans examiner les plaques des rues. La clarté intense, le grand mouvement l'etourdissaient. Il entra dans un café, et en se levant il traina les pieds, comme s'il portait encore des tamancos" (RAMOS, R., 1988, p. $688)^{8}$. Ao hesitarem a traduzir a recorrente referência a "tamancos", os tradutores, também, demonstram um receio de rasura como quem lida com uma palavra que testemunha o que nenhuma outra faria em seu lugar. De fato, a palavra testemunha.

Por outro lado, em outros momentos do seu testemunho, Graciliano expressa um sentimento ambivalente em relação ao peso dos tamancos, peso ilustrado no trecho acima. Na mudança para a temida Colônia Correcional, deixa para trás os calçados de madeira e, diante disso, afirma, comparando-os aos sapatos fechados que machucavam seus pés: "os tamancos deixados no cubículo 50, no pavilhão dos primários, faziam-me falta. [...] Os tamancos me dariam folga, relativa liberdade" (RAMOS, 1954, vol. 3, p. 62). Naquele momento, já não estava mais afeito ao tipo de calçado que usava fora da prisão e, talvez, até mesmo à relativa liberdade, à vida além das barras de ferro. Esse lapso otimista e contraditório em ver a possibilidade de liberdade naquilo mesmo que, no decorrer da narrativa, surge como marca do cárcere, não se distancia de um sintoma traumático, como poderíamos inferir. $\mathrm{O}$ contraste de sentimentos e expressões, como o uso do tom irônico na representação da conjuntura fúnebre e triste em Memórias do cárcere, é um

8. A Explicação Final, anexa ao último volume de Memórias do Cárcere, é um texto escrito por Ricardo Ramos, filho de Graciliano. Nele, afirma-se a falta de um capítulo derradeiro, cuja escrita, prometida e postergada pelo autor, não havia sido findada. No trecho, parece-nos que Ricardo Ramos testemunha as primeiras sensações de Graciliano fora do cárcere. Assim, lemos no texto original: "e procurava orientar-se através de reminiscências, sem examinar as placas. A claridade forte, o movimento grande o atordoavam. Entrou num café, e ao levantar-se arrastou os pés, como se ainda usasse tamancos" (RAMOS, R. 1954, vol. 4, p. 163). 
traço melancólico (OLIVEIRA, 2014). O sofrimento, o trauma e a ferida gestam a melancolia manifesta nessa ambivalência. Diante do risco do silêncio pela situação limite intraduzível, "a linguagem só pode se fazer retratando esse sentimento melancólico ambíguo, ou seja, através de paradoxos e oximoros (a cadeia: "princípio de libertação")" (OLIVEIRA, 2014, p. 161).

Já na escrita tradutória, a significação nesse trecho carrega um traço menos otimista e, consequentemente, menos contraditório. Os tradutores então escrevem : "les tamancos auraient donné à mes pieds de l'espace et une relative liberté" (RAMOS, 1988, p. 432). Aqui, fica muito mais clara a referência aos pés machucados com o uso dos calçados aos quais Graciliano já se desabituara. Fica mais distante a perspectiva otimista e irônica que se lê na escrita de Graciliano. Podemos presumir que, para os tradutores, os tamancos representam o trauma do cárcere, de modo que esses calçados não poderiam proporcionar à testemunha uma sensação de liberdade, ainda que de uma "relativa" liberdade. Nesse deslocamento, faz-se "ouvir" a voz dos tradutores no gesto testemunhal, isto é, eles assumem a posição de testemunha, não a mesma posição de Graciliano, mas uma outra, a partir da qual são atormentados por um trauma representado nos tamancos. $\mathrm{O}$ tormento que esses calçados causam na escrita de Seel e Coli é tamanho que se torna impossível testemunhar neles um princípio de liberdade.

Em vista dessas "escolhas" na escrita de Mémoires, afirmamos que os tradutores testemunham um trauma indizível/intraduzível na palavra tamancos e relevam esse trauma na escrita tradutória, oferecendo-o ao testemunho do leitor como a marca estranha e inassimilável de uma ferida que atestam no original. Entrevemos nesse gesto (in)tradutório o argumento derridiano da irredutibilidade da escrita poética ou testemunhal a um certo número de sentidos, conteúdos ou referências transferíveis a outros significantes, a outro presente, à outra escrita. As feridas inscritas e lidas nas palavras não são da ordem meramente de uma verdade ou de um "âmago" a ser "descoberto" e "traduzido". As palavras carregam o peso de um trauma que apenas elas e as suas testemunhas puderam e podem testemunhar.

\section{CONSIDERAÇÕES FINAIS}

$\mathrm{Na}$ leitura de Memórias do cárcere, percebemos certa angústia no esforço tradutório para dizer o indizível, para quitar a dívida insolvável da representação, no corpo textual, das marcas de um corpo ferido. Na escrita de um passado traumático, Graciliano Ramos aproxima a sua tarefa ora a um retorno à "cova", ora a um processo de ressuscitar daquele "mundo horrível de treva e morte" (RAMOS, 1954, vol.1, p. 
7). $\mathrm{Na}$ indecidibilidade do seu testemunho de ser inscrito entre a morte a ameaçar o resto de vida pós-cárcere, e a sobrevivência, vislumbramos o peso da sua tarefa. Entrevemos, como discutido anteriormente, uma tensão tradutória, ou seja, um abalo na tentativa de dizer "o mesmo" entre memória e língua. Confirma o conflito tradutório no original a forma como os tradutores descrevem a escrita das Memórias de Graciliano: "um estilo retido, tenso ao extremo, como uma corda prestes a se romper $^{\prime \prime}$ (COLI; SEEL, 1988, p. 13, tradução nossa).

Somando à tensão que atestam, os tradutores qualificam essa escrita como "áspera" e "acerada", condizente com "a posição do autor face à realidade", diante do "horror dos fatos narrados" (COLI, SEEL, 1988, p. 13) 10. No aspecto "áspero", "acerado" e "tenso" com o qual Seel e Coli se veem às voltas, inferimos uma escrita que, não apenas está marcada e ferida pelo trauma que narra, mas que também afeta e fere aqueles que se encontram diante da sua "aspereza". O texto se torna, portanto, performance da realidade contundente que relata, transformando seus tradutores em testemunhas da tensão e do peso de uma escrita "acerada". Tal é a escrita tensa que os tradutores testemunham e suplementam na tradução.

O peso da tarefa tradutória, juntamente com a tradição de rebaixamento dessa prática, impulsiona a desconfiança dos tradutores nas escolhas para traduzir palavras que supostamente são testemunhas "privilegiadas" de um trauma no original. No entanto, essa tensão tradutória já se manifesta na escrita de Graciliano, como os tradutores atestam em seu prefácio. Tal conflito é, portanto, dobrado na tradução. Em vista disso, ela se revela testemunho não de um terceiro a falar pela testemunha original, mas de testemunhas "diretas" afetadas pela escrita "tensa", como uma "corda prestes a se romper" diante do compromisso infindável de traduzir a dor nas palavras.

Como vimos, a aporia tradutória da qual Derrida (2000b) fala se faz também manifesta no texto de partida para Mémoires de prison. A equivalência que se busca entre trauma e escrita não chega a ser alcançada satisfatoriamente, de modo que entre o corpo ferido e corpo textual persiste um espaçamento. Malgrado as tentativas de aproximar esses corpos, o espaçamento persiste impondo ao escritor/ testemunha a experiência da différance, da diferença e do adiamento desse encontro ideal entre trauma e letra, em que um se tornaria presente no outro e, então, seria testemunhável a qualquer leitor, apropriável e traduzível em qualquer língua.

9. "...un style tenu, tendu à l'extreme, comme une corde prête à se rompre".

10. Segundo seus tradutores, "cette écriture, si acérée, si âpre, ne se veut pourtant pas un constat froid et objectif, destiné à mieux faire ressortir l'horreur des faits narrés. Il s'agit encore moins d'un art de la suggestion - cette forme sonvent insidieuse de l'exagération. Ce style correspond à la position de l'auteur face à la realité, qui exclut le sentimentalisme et l'emphase rbétorique" (COLI ; SEEL, 1988, p. 9-10) 
O espaçamento entre acontecimento e escrita se oferece, portanto, como uma ferida que não se fecha, ferida à qual Derrida (2007) alude numa discussão em torno da alteridade, da assinatura e do acontecimento da escrita como abertura desse corte, em que resiste a différance entre o trauma e a promessa de traduzi-lo. Nesse sentido, o testemunho de Graciliano e dos tradutores revelam e relevam "uma ferida noutra ferida" (DERRIDA, 1995), um trauma que se sofre antes da escrita e no processo escritural, na busca por amarrar o passado à língua, busca que traz a dor de recordar o trauma e defrontar com o limite da tradução e do testemunho.

A escrita, a leitura e a tradução das Memórias do cárcere dão testemunho de uma ferida, de um espaçamento, de uma cesura desde o testemunho que chamamos de original, mas que engendra em si um processo tradutório. No seu prefácio, os tradutores atestam tal ferida quando falam da desconfiança nas palavras que percebem na escrita de Graciliano Ramos. Seel e Coli acabam por reproduzir essa desconfiança que testemunham no original quando não traduzem os tamancos, o Nordeste, o sertão e a senzala, quando optam por deixar essas palavras ecoarem os traumas que testemunham em sua língua. Não obstante, persiste a incerteza de que o leitor de Mémoires de prison ouvirá o que essas palavras estrangeiras testemunham em Memórias do cárcere. As notas dos tradutores confessam tal incerteza e são testemunho de uma différance insolvável, de uma ferida que não se fecha.

\section{REFERÊNCIAS}

BENTO, C. A. (2010). A fissura e a verruma: corpo e escrita em Memórias do Cárcere. São Paulo: Humanitas.

CELAN, P. (1967). Cinzoglória. Tradução de Piero Eyben. In: MICHAUD, G. Aschenglorie, de Paul Celan: "ponto de intraductibilidade", as questões de uma tradução "relevante" de Jacques Derrida. Tradução de Gabriela Lafetá Borges e Piero Eyben. Cerrados. v. 21, no. 33, 2012, pp. 275-310.

COLI, J.; SEEL, A. (1986). Um escritor que desconfia das palavras. Folba de São Paulo, Ilustrada, 16 ago., p. 66.

COLI, J.; SEEL, A. (1988). Prefácio. In: RAMOS, G. (1953) Mémoires de prison. Tradução de Antoine Seel e Jorge Coli. Paris: Gallimard, pp. 9-16.

CRÉPON, M. (2006). Traduire, Témoigner, Survivre. Rue Descartes, n. 52, pp. 27-38. 
DERRIDA, J. (1972). A diferença. In: DERRIDA, J. Margens da filosofia. Tradução de Joaquim Torres Costa e António M. Magalhães. Campinas: Papirus, 1991, pp. 33-63.

DERRIDA, J. (1972). Assinatura acontecimento contexto. In: DERRIDA, J. Margens da filosofia. Tradução de Joaquim Torres Costa e António M. Magalhães. Campinas: Papirus, 1991, pp. 349-373.

DERRIDA, J. (1998). Demeure: fiction and testimony. Tradução de Elizabeth Rottenberg. California: Stanford University Press, 2000a.

DERRIDA, J. (1998). O que é uma tradução relevante?. Tradução de Olivia Niemeyer Santos. Alfa, v. 44, n.esp, pp. 13-44, 2000b.

DERRIDA, J. (2003). Béliers Le dialogue ininterrompu: entre deux infinis, le poème. Paris: Galilée.

DERRIDA, J. (2004). Poétique et politique du témoignage. Cabier de L'Herne. Éditions de L’Herne, no 83 , pp. 521-539.

DERRIDA, J. (2005). Fidelidade a mais de um: merecer herdar onde a genealogia falta. Tradução e organização de Paulo Ottoni. In: OTTONI, P. (2005). Tradução manifesta: Double bind e acontecimento. Campinas: Editora da Unicamp, pp. 165-198.

DERRIDA, J. (2004). A verdade ofensiva ou o corpo-a-corpo das línguas. Tradução de Élida P. Ferreira. Especiaria: Cadernos de Ciências Humanas. v. 10, n. 17, pp. 305-329, 2007.

JAKOBSON, R. (1959). Os aspectos linguísticos da tradução. Tradução de Izidoro Blikstein e José Paulo Paes. In: JAKOBSON, R. Linguística e comunicação. 20a ed. São Paulo: Cultrix, 1995.

MARTINEZ, C. M. (2002). Imagens do cárcere: do texto literário à leitura cinematográfica. Dissertação de mestrado em letras. Departamento de Ciências Humanas, Letras e Artes, Universidade Federal do Paraná, Curitiba.

NOVAES, C. C.; SOUZA, M. C. B. de. (2018). Transculturalidade e trânsitos intersemióticos: adaptações e transcriações cinematográficas em Graciliano Ramos. Pontos de Interrogação, v. 8, n. 1, pp. 91-106.

OLIVEIRA, A. M. A. dos S. (2014). Memória, testemunbo e escrita melancólica em Memórias do cárcere e Infância, de Graciliano Ramos. Tese de doutorado em Estudos de Literatura. Instituto de Letras, Universidade Federal Fluminense, Niterói. 
PAVERCHI, S. R. (2004). A obra literária e cinematográfica de Memórias do cárcere de Graciliano Ramos: o cárcere como metáfora da sociedade e a ficção como busca da libertação. Dissertação de mestrado em Comunicação e Semiótica. Pontifícia Universidade Católica de São Paulo, São Paulo.

RAMOS, G. (1953). Memorias do cárcere. Vol 1 - Viagens. $3^{\text {a }}$ Ed. Rio de Janeiro: José Olympio, 1954.

RAMOS, G. (1953). Memorias do cárcere. Vol. 3 - Colônia correcional. Rio de Janeiro: Jose Olympio.

RAMOS, R. (1953). Explicação final. In: RAMOS, G. Memorias do cárcere. Vol. 4 - Casa de correção. $3^{\mathrm{a}}$ Ed. Rio de Janeiro: Jose Olympio. 1954.

RAMOS, G. (1953). Mémoires de prison. Tradução de Antoine Seel e Jorge Coli. Paris: Gallimard, 1988.

SELIGMANN-SILVA, M. (2005). O local da diferença: ensaios sobre memória, arte, literatura e tradução. São Paulo: Editora 34.

SILVA, V. G. I. (2015). O gesto autoral e o testemunbo em Memórias do Cárcere. Dissertação de mestrado em Literatura e Crítica Literária. Pontifícia Universidade Católica de São Paulo, São Paulo.

Recebido: $13 / 12 / 2019$

Aceito: 30/6/2020

Publicada: 4/8/2020 